\title{
RESTRICTED
}

CEPAL/WAS/R.15

Apri1 1981

ORIGINAL: ENGLISH

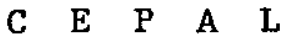

Economic Commission for Latin America

Washington office

RECENT TRENDS IN THE

WORLD ECONOMY*

*/ This draft report, prepared by Robert Dev1in of CEPAL's Washington Office, is a contribution to the 1980 Economic Survey of Latin America. The opinions expressed in this paper are those of the author and do not necessarily represent those of CEPAL. 


\section{RECENT TRENDS IN THE WORLD ECONOMY}

Since the mid-1970s the world economy has evidenced a marked slowdown from the unprecedented growth and prosperity that was enjoyed in the two decades following World War II. While it is uncertain whether the downturn is due to cyclical or structural factors, whether it is of a temporary or permanent nature, it is nevertheless evident that the slowdown is more prolonged and severe than might have been contemplated by many when the open manifestations of world-wide economic problems first appeared in late 1973. $1 /$ Moreover, as will become clear from the ensuing analysis, events in 1979-1980 represent a second major setback for a world economy that had been displaying some signs of successful adjustment to the we11-known economic shocks of 1973-1974.

1/ Some recent work has stressed the structural character of the current slowdown in the world economy. See Lester Thurow The Zero Sum Society, N.Y., Basic Books, 1980 and Ronald Müller Revitalizing America, N.Y. Simon \& Schuster, 1980. The Bank for International Settlements in its Forty Eighth Annual Report (Basle, June 1978) also suggests structural factors behind current problems and even raises the possibility that the world economy is in a Kondratieff type of slowdown. W. Arthur lewis, on the other hand, points out in a recent article that many of the indicators of economic malaise such as high umemployment, low profits, low investment ratios, etc. are merely elements of a cyclical swing and in and of themselves are not evidence of a secular decline in growth. While not dismissing the possibility that the recent decline in growth rates is of a more permanent nature, he points out that the slowdown nevertheless displays characteristics similar to 4 other cyclical downturns that have occurred since 1873 and which have had a duration of roughly 10 years. See $W$. Arthur Lewis, "The Slowing Down of the Engine of Growth" American Economic Review, September 1980, pp 555-564. 


\section{OUTPUT}

In 1980 the growth of world output slipped to only $2.2 \%$, which is considerably below the growth rate of $3.8 \%$ achieved in 1979 and less than half of the recovery rate of $4.7 \%$ recorded in $1976-1978$. Moreover, the slowdown was all pervasive, as every major country group suffered a serious loss of dynamism in economic activity (See table 1). The most severe reduction in output growth was in the developed market economies, (which basically represent the OECD area), as their joint Gross Domestic Product rose by only $1.5 \%$, compared to nearly $4 \%$ the year before. The centrally planned economies also experienced slippage in their growth rates with respect to the modest expansion of 1979 . As for the developing countries, they suffered a serious setback to their growth aspirations, with output expanding by nearly $1 \%$ less than the already modest rate of $4.8 \%$ recorded in 1979 ; indeed growth was only slightly higher than that recorded in the deep recession of 1975 . The gravity of the world recession in 1980 can perhaps be better appreciated by viewing data on world industrial production in table 2 . Here it is seen that the volume of world industrial output grew by only $1.5 \%$ in 1980 , the second worst performance of the decade. (In 1975 output underwent an absolute decline.) It also can be seen that in this same year the growth of industrial output in the developed market economies was virtually $\mathrm{nil}$ in 1980 , while the expansion in the developing countries was a disappointing $1.8 \%$. In 1975 , when world industrial production plummeted in absolute terms, the centrally planned economies managed to insulate themselves from overall trends; this was clearly 
TABLE 1

WORLD GROSS DOMESTIC PRODUCT

(percentage rates of growth

in real terms)

\begin{tabular}{|c|c|c|c|c|}
\hline Country Groups & $\begin{array}{l}1971- \\
1980\end{array}$ & $\begin{array}{l}1976- \\
1978 \\
\end{array}$ & 1979 & $1980^{a}$ \\
\hline World & 4.1 & 4.7 & 3.8 & 2.2 \\
\hline Centrally Planned $\underline{b} /$ & 5.5 & 5.5 & 3.3 & 3.1 \\
\hline Developed Market Economies $c$ / & 3.3 & 4.3 & 3.7 & 1.5 \\
\hline Developing Countries $\mathrm{d} /$ & 5.7 & 5.2 & 4.8 & 3.9 \\
\hline
\end{tabular}

Source: Cepal on the basis of official data.

af preliminary

b/ The data are for Eastern Europe, USSR and China and represent net material product.

c/ Includes South Africa

d/ Includes Israel and Turkey 
WORLD INDUSTRIAL PRODUCTION

(growth rates in real terms)

\begin{tabular}{|c|c|c|c|c|c|c|c|c|c|}
\hline & 1973 & 1974 & 1975 & 1976 & 1977 & 1978 & 1979 & 1980 a / & $\frac{\text { Average }}{1968-78}$ \\
\hline WORLD & 8.9 & 2.4 & -3.4 & 8.1 & $\underline{4.6}$ & $\underline{4.2}$ & 4.4 & $\underline{1.5}$ & 7.1 \\
\hline Centrally Pianned $\underline{b}$ & 8.9 & 8.8 & 8.3 & 6.5 & 6.5 & 5.7 & 4.3 & 3.8 & 11.4 \\
\hline $\begin{array}{l}\text { Developed Market } \\
\text { Economies c }\end{array}$ & 8.9 & - & -7.2 & 8.4 & 3.1 & 4.1 & 5.0 & $0: 4$ & 5.3 \\
\hline $\begin{array}{l}\text { Developing } \\
\text { countries }\end{array}$ & 10.8 & 3.3 & -4.4 & 9.1 & 5.8 & 2.0 & $2 \cdot 4$ & 1.8 & 8.4 \\
\hline
\end{tabular}

Source: Calculated from data in United Nations, Monthly Bulletin of Statistics, February 1981, and estimates of CEPAL. a/ Preliminary

b/ Eastem Europe, USSR, and China.

c/ Includes Israel and South Africa. 
not the case in 1980 however, as expansion of industrial output was considerably less than half of that of 1973-1974.

Turning to slightly more detailed examination of the economic blocs, it is seen that the downturn in the OECD area was generalized, but not as severe as that which was experienced in 1974-1975. (See table 3). Leading trends were the United States and the United Kingdom where output declined in absolute terms. The primary factor underlying events was a roughly $140 \%$ increase in the average price of petroleum $1 /$ in 1979-1980 that eroded the area's terms of trade and reduced incomes by an estimated $21 / 4 \%$. $2 /$ S1ower growth of personal incomes adversely affected residential investment, which also was severely hurt by tight monetary policies which introduced extraordinarily high domestic interest rates in many OECD countries (see table 4). Furthermore, fiscal restraint has become a watchword in many countries and thus trends in government consumption introduced a procyclical contractionary effect. Non-residential investment also sagged in this depressed environment, but notably it did not collapse, as was the case in 1975, apparently due to the fact that investors were somewhat better conditioned to withstand upheavals brought about by changing world oil prices.

Growth of material product in the Soviet Union and Eastern European countries is estimated to have been about $2.9 \%$ in 1980 , slightly

$1 /$ The annual average of ficial price of OPEC crude rose from 12.93 dollars in 1978 to 30.87 dollars in 1980 . The bulk of the price rise took place in 1979, with the price stabilizing at around 32 dollars by mid-1980.

2/ See OECD, Economic Outlook No. 28, December 1980, p.13 


\section{TABLE 3}

OECD: GROWTH RATES OF GNP

(percentage change in real terms)

\begin{tabular}{|c|c|c|c|c|c|c|c|c|c|}
\hline & 1973 & 1974 & 1975 & 1976 & 1977 & 1978 & 1979 & 1980 a $/$ & $\frac{\text { Average }}{1968-78}$ \\
\hline$\underline{\mathrm{OECD}}$ & $\underline{6.3}$ & $\underline{0.7}$ & -0.5 & $\underline{5.3}$ & 3.7 & 3.9 & 3.3 & 1.4 & $\underline{3.8}$ \\
\hline United States & 5.4 & -1.3 & -1.0 & 5.6 & 5.1 & 4.4 & 2.3 & -0.2 & 2.9 \\
\hline Japan & 10.0 & -0.3 & 1.4 & 6.5 & 5.4 & 5.9 & 5.9 & 5.5 & 6.6 \\
\hline Germany & 4.9 & 0.5 & -1.8 & 5.2 & 3.0 & 3.3 & 4.5 & 1.8 & 3.5 \\
\hline France & 5.4 & 3.2 & 0.2 & 5.2 & 2.8 & 3.6 & 3.3 & 1.6 & 4.4 \\
\hline United Kingdom & 7.5 & -1.2 & -0.8 & 4.2 & 1.0 & 3.6 & 1.5 & -3.0 & 2.3 \\
\hline
\end{tabular}

Source: OECD Economic Outlook No. 28, December 1980, and CEPAL on the basis of official data.

a / preliminary. 


\section{TABLE 4}

COMMERCIAL BANK LENDING RATES TO PRIME BORROWERS FOR SELECTED COUNTRIES

(percentage rate at the end of December)

\begin{tabular}{|c|c|c|c|c|c|}
\hline & 1976 & 1977 & 1978 & 1979 & 1980 \\
\hline United States & 6.00 & 7.75 & 11.75 & 15.25 & 21.50 \\
\hline Japan & 7.42 & 5.47 & 4.50 & 6.31 & 8.30 \\
\hline Germany & 6.50 & 6.00 & 5.50 & 9.75 & 11.50 \\
\hline France & 11.65 & 11.35 & 10.95 & 13.65 & 13.40 \\
\hline United Kingdom & 15.50 & 8.00 & 13.50 & 18.00 & 15.00 \\
\hline
\end{tabular}

Source: Morgan Guaranty Trust, World Financial Markets, January 1980, p. 20, and February 1981. p. 18. 
higher than the low rate of $2.5 \%$ recorded in 1979 , but well below the average expansion of $6.3 \%$ achieved in 1971-1975. The Soviet Union - -bolstered by a favorable terms of trade, due in part to petroleum exports-- was actually able to significantly expand real output in 1980 . This was not the case for the Eastern European countries, however, which generally were encountering difficult situations with regard to external balances that necessitated a tight rein on economic activity. (In the case of Hungary and Poland, output declined in absolute terms.) It also should be added that the economic performance in this group of countries was handicapped by the second consecutive year of poor agriculture output: it is estimated that production declined by $3 \%$ in 1980 , following a $2 \%$ drop in 1979 .

In China there was a slowing down of production in industry and agriculture from a rate of more than $6 \%$ in 1979 , to something less than $5 \%$ in 1980. Poor harvests were a major factor behind this performance, but there also was a noticeable slackening in the rate of growth of heavy industry.

It is evident that in 1980 the developing countries were unable to insulate themselves from the world recession as they did in 1975; growth rates were uniformily low in this group of countries. As seen in table 5, only South and East Asian countries were able to accelerate growth with respect to 1979 .

Countries that are net exporters of petroleum saw their growth rates slip from $5.5 \%$ in 1979 to $4.0 \%$ in 1980 . A primary factor behind the less dynamic performance was the reduced petroleum production -. that was induced by the recession in the OECD and mild winter weather in the North. The Iran-Iraq war was an additional factor. But it also should be mentioned that a number of oil producers have been deliberately targeting milder 
TABLE 5

DEVELOPING COUNTRIES: GROSS DOMESTIC PRODUCT

(growth rates in real terms)

\begin{tabular}{|c|c|c|c|c|c|}
\hline & $1971-1980$ & $1976-1978$ & 1978 & 1979 & $19 \dot{8} 0$ a $/$ \\
\hline Africa $b /$ & 4.8 & 6.0 & 4.8 & 6.2 & 5.3 \\
\hline South \& East Asia & 5.6 & 6.8 & 7.1 & 2.9 & 4.7 \\
\hline -Western Asia c/ & 6.4 & 2.8 & 1.4 & 3.7 & 0.5 \\
\hline $\begin{array}{l}\text { Latin America and the } \\
\text { Caribbean d/ }\end{array}$ & 5.8 & 5.0 & 4.5 & 6.2 & 4.8 \\
\hline \multicolumn{6}{|l|}{ Memorandum item } \\
\hline Net energy exporters & 5.8 & 5.0 & 4.1 & 5.5 & 4.0 \\
\hline Net energy importers & 5.6 & 5.4 & 5.0 & 4.3 & 3.9 \\
\hline
\end{tabular}

Source: Cepal on the basis of official data.
a/ Preliminary
b/ Excludes South Africa
ch Includes Israel and Turkey
d/ Due to methodological differences, these data are not perfectly compatible with - those found in later sections of the Economic Survey. 
growth rates in order to minimize the social and economic disturbances that can be associated with rapid growth; meanwhile some countries. are focussing their projects on social development which in the near term tends to produce less dramatic rates of economic expansion.

In 1980 growth sagged further for the net importers of energy (see again table 5) on account of an adverse terms of trade and less favorable conditions for securing finance to support high growth rates. Some large countries such as Brazil and India were able to accelerate their growth rates in 1980 on account of recoveries in agricultural production. While still other countries also enjoyed better harvests, on a per capita basis there was no gain in agricultural output for this group of countries. ${ }^{\prime \prime}$ On balance it seems fair to say that the 1980 growth performance represents an unfortunate setback to the non-oil exporting developing countries, which have tried so hard to sustain high growth rates in the face of the current difficult world economic environment.

$1 /$ See GATT, Press Release, 10 March 1981, p.7. 


\section{PRICES}

Serious inflationary pressures continued to plague the world economy even in the face of ^̀sharp economic slowdown in all geographic areas.

In the OECD area, prices rose, on an annual average basis, by $12.5 \%$ in 1980 , which is a marked increase over the $9.8 \%$ rate of 1979 and roughly 4-times the rate of increase in prices that was recorded in the decade of the 1960s (see table 6). Among the major OECD countries, there was a uniform worsening of the inflationary situation: Japan saw its rate of inflation more than double in 1980, and that of the U.K. increasee by more than a third; meanwhile, the U.S., which has traditionally enjoyed one of the most stable price structures in the world, had the 11 th worst rate of inflation in the 24-nation OECD group. Not surprisingly, one of the major elements behind the deterioration in price performance was adjustment to higher energy costs, but higher food prices also contributed to the inflationary spiral. Notably, wages were not a major inflationary factor as wage demands have been surprisingly restrained since $1978.1 /$ It is interesting to note that some of the worst inflationary performances were in countries with significantly appreciating exchange rates (see table 7), which would be consistent with the notion that domestic prices tend to be rigid downwards.

It is notable that for the first time in recent years inflation also has become a problem in some centrally planned economies. While in most countries official prices moved very little, this was accomplished only by official intervention in markets and growing fiscal subsidies. In other countries that have tended to rely somewhat t nmon $\quad . \quad \ldots$ in in 
$\underline{\text { TABLE }} 6$

OECD: CONSUMER PRICES

(percentage average change over previous period)

\begin{tabular}{|c|c|c|c|c|c|c|}
\hline & $\frac{\text { A v }}{1961-1970}$ & $\frac{\mathrm{e}}{1971-1976}$ & 1977 & 1978 & 1979 & $1980 \underline{a} /$ \\
\hline OECD & $\because 0$ & 8.5 & $\underline{8.9}$ & 7.9 & $\underline{9.8}$ & $\underline{12.5}$ \\
\hline United States & 2.8 & 6.6 & 6.5 & 7.7 & 11.3 & 13.5 \\
\hline Japan & 5.8 & 11.2 & 8.1 & 3.8 & 3.6 & 8.0 \\
\hline Germany & 2.7 & 5.9 & 3.7 & 2.7 & 4.1 & 5.5 \\
\hline France & 4.0 & 9.0 & 9.4 & 9.1 & 10.8 & 13.3 \\
\hline United Kingdom & 4.1 & 13.6 & 15.8 & 8.3 & 13.4 & 18.0 \\
\hline
\end{tabular}

Source: OECD Economic Outlook, December 1980, No. 26, p. 47; IMF International Financial Statistics and Cepal on a/ Preliminary. 


\section{TABLE 7}

REAL EFFECTIVE EXCHANGE RATES FOR SELECTED

INDUSTRIALIZED COUNTRIES, 1973-1980 a /

$(1973=100)$

\begin{tabular}{lrrrrr}
\hline & $\begin{array}{l}\text { United } \\
\text { States }\end{array}$ & Japan & $\begin{array}{l}\text { United } \\
\text { Kingdom }\end{array}$ & Germany & France \\
\hline 1973 & 100.0 & 100.0 & 100.0 & 100.0 & 100.0 \\
1974 & 95.1 & 99.4 & 100.8 & 105.3 & 94.7 \\
1975 & 98.6 & 87.9 & 104.3 & 100.4 & 102.6 \\
1976 & 100.1 & 88.9 & 96.6 & 101.2 & 100.1 \\
1977 & 99.9 & 93.7 & 101.7 & 102.7 & 96.6 \\
1978 & 95.5 & 107.5 & 106.5 & 103.4 & 97.3 \\
1979 & 95.6 & 96.2 & 118.9 & 104.2 & 99.2 \\
1980 & 97.8 & 93.9 & 137.1 & 101.2 & 101.0 \\
\hline
\end{tabular}

Source: Morgan Guaranty Trust, World Financial Markets (various issues)

a/ The index of the real effective exchange rate is based on the trade weighted exchange rate

adjusted for inflation differentials which are measured by wholesale prices of non-food manufactures. 
more on market forces, e.g. Poland, Hungary and China, necessary price adjustments have been rather severe, i.e. $7 \%$ to $9 \%$ annually. As for the developing countries, the economic shocks of 1979-1980 occurred when many countries were already grappling with serious internal stabilization problems, and events in these years only served to aggravate the situation. In 1980 inflation showed serious acceleration in all regional groups, although the countries of South and East Asia continued to stand out for remarkably moderate rates of inflation as compared to other developjng areas. (See table 8.) The very high level of inflation in developing countries is sufficient evidence of the domestic factors underlying inflationary presaures. However, the internal rate of price increāse also has undoubtedly been impacted by external events such as higher import prices for key goods, e.g., energy and manufactuxed items, and devaluations brought on by weakening external balances. Another significant factor is "adjustment" inflation steming from the fact that many developing countries are eliminating subsidies, freeing interest rates, etc, in order to achieve a more efficient allocation of resources in their domestic economies. 


\section{TABLE 8}

Developing Countries: Change in Consumer Prices a (percentage)

\begin{tabular}{|c|c|c|c|c|c|c|c|}
\hline Country Group & $1969-1972$ & $1973-1979$ & 1977 & 1978 & 1979 & \multicolumn{2}{|c|}{$\begin{array}{r}\text { Jan-June } \\
1979-1980\end{array}$} \\
\hline Developing Countries b/ & 8.9 & $\underline{19.4}$ & 21.3 & 18.3 & 24.4 & $\underline{23.2}$ & 41.6 \\
\hline Africa $\underline{c} /$ & 6.1 & 15.7 & 18.6 & 17.5 & 16.3 & 17.0 & 18.8 \\
\hline South \& East Asia & 6.6 & 12.6 & 8.7 & 6.4 & 11.7 & 9.4 & 13.5 \\
\hline West Asia $\underline{d} /$ & 6.5 & 21.1 & 24.2 & 24.3 & 31.5 & 32.2 & 84.4 \\
\hline Latin America \& the Caribbean e/ & 12.4 & 26.0 & 32.6 & 27.0 & 35.8 & 33.5 & 55.5 \\
\hline
\end{tabular}

Source: IMF International Financial Statistics (various issues) and Cepal on the basis of official data.

af Annual averages

b/ Includes Yugoslavia and excludes Argentina, Chile and Ghana

c/ Excludes Ghana and South Africa

d/ Includes Israel \& Turkey

ef Excludes Argentina \& Chile 


\section{TRADE}

GATT has estimated that world merchandise trade reached nearly 2.000 billion dollars in 1980 , an increase of $20 \%$, compared to a rise of: $25 \%$ in 1979. Almost all the rise was due to price increases, however, as volume was s..uggish and rose by only 1 percert, one of the lowest rates of increase in the last 25 years. (In 1979: trade volume grew by 6\%.) The less dynamic trade performance reflected a sharp absolute decline in the volume of petroleum exports and a fall in the growth rate of world trade in manufactures, from $5.5 \%$ in 1979 to roughly $3 \%$ in 1980 . Growth of agricultural trade volume also may have decelerated to $4 \%$ from the $7 \%$ rate of expansion of 1980. If petroleum is excluded from consideration, world trade volume expanded by $4 \%$ in $1980.1 /$

In the developed market economies, the value of exports and imports rose by 17 and 19\%, respectively, in 1980 (see table 9\%) The growth of imports was due entirely to higher prices, as volume declined by nearly $2 \%$, compared to an $8 \%$ rise in the previous year. Export growth also mostly reflected price trends, as volume rose by only slightly more than $3 \%$. (It was $6.5 \%$ in 1979.) The terms of trade loss in 1980 was roughly $8 \%$.

If one examines the OECD area it becomes evident that developing countries' imports are playing a significant role in helping to sustain overa11 growth rates. In 1980 the volume of OECD exports to OPEC countries rose by $20 \%$, and with respect to the non-oil developing countries the rise was $4 \%$; both rates exceeded those recorded for intra-OECD trade. $\underline{2}$ GATT, focussing on trade in manufactured goods, has noted that in 1980 the oil exporters accounted for near 1 y $10 \%$ of the industrialized countries' exports, a new peak level. On a net basis, the trade surplus in manufactured goods with the oil exporters was 82 billion dollars in $1980,33 \%$ greater $1 /$ See GATT, op. cit, p.1

2/ See OECD, op. cit, p.55 
TABLE 9

VALUE OF WORLD TRADE BY ARËAS a/

(billions of dollars) :

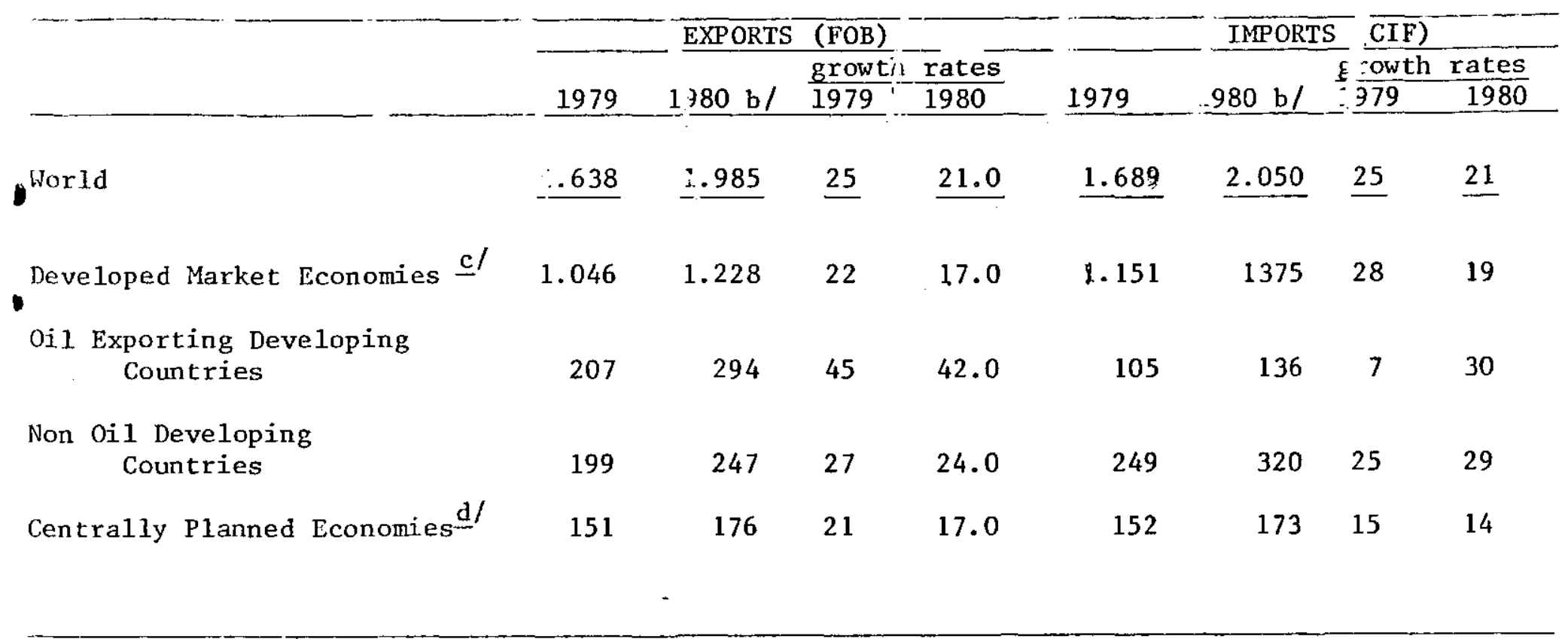

Source: GATT, Press Release, 10 March 1981

a/ Please note that due to different sources of information the country classifications used in this table are not entirely compatible with those employed in earlier tables of this world summary.

bl Preliminary

cf Includes South Africa

- 1 f FOB 
previous year. While it is estimated that the value of trade in manufactures between the industrialized countries and the non-oil developing countries slowed down som what from the $25 \%$ rate of growth recorded in 1979 , trade f1ows vith thes!? countries continued to be the fistest groing ones for : ndustria:ized coun ries. $1 /$

Withi.l the centrally planned economi's, trade lerformances varied considerably. The Eastern European countries, concerned about their external indebtedness with international commercial banks, pushed export volume up by rough 1 y $3 \%$, while completely containing the real growth of their imports. The Soviet Union, however, as a net exporter of petroleum enjoyed a favorable terms of trade and was able to expand import volume by about. $5 \%$, while exports rose in volume by a little more than one percent. Meanwhile, China was able to reduce a trade deficit largely on account of severe restrictions on imports.

The oil exporting developing countries exports rose by $42 \%$ in value in 1980 entirely on the basis of rising world petroleum prices; the volume of exports declined quite sharply, estimated to be somewhere near $13 \%$. Needless to say the lower volume reflected the effects of sluggish world economic activity and general efforts at conservation of energy. Unlike 1979 when import volume tended to stagnate, in 1980 these countries imports showed renewed and vigorous growth; they rose by $30 \%$ in value, compared to $7 \%$ in 1979 , and volume was up by around / the

15\%. As already noted, the imports of/oil exporters in 1980 was an important factor in the trade performance of the industrialized countries, but they also did considerable importing from non-oil developing countries and were a significant factor in this latter group's efforts 1) See GATT, op. cit, p.11 
to sustain their export drive.

The non-oil developing countries expanded the value of their exports by almost one quarter in 1980 , while their imports rose by nearly $30 \%$ ( ee again table 9.) Export earnings were pushed up basically by higher prices as volume expanded by on $1 y 3 \%$. Prices for primary commodities (excluding petroleum) of developing countries displayed considerably dynamism in 1980 (see table 10) and it is estimated that for the year as a whole the rise in prices was $17 \%$, which compares favorably to a $12 \%$ increase in the price of manufactured goods exported by developed countries. of course, the actual impact of prices depends on the commodity composition of exports; for instance, sugar exporters enjoyed a dramatic increase in prices that exceeded $150 \%$ (due to production shortfalls in Cuba and the USSR), while coffee producers saw their export prices slacken in 1980. In any event, when petroleum is accounted for, the non oil exporting developing countries encountered a serious deteriotation of their terms of trade. The overall effect was a $46 \%$ increase in this groups trade deficit in 1980 . (See again table 9.) :

I/ See GATT, op. cit., p. 4 
TABLE 10

PRICES OF PRIMARY COMMODITIES

$(1975=100)$

\begin{tabular}{|c|c|c|c|c|c|c|c|c|c|}
\hline & 1973 & 1974 & 1975 & 1976 & 1977 & 1978 & 1979 & \multicolumn{2}{|c|}{ JAN-SEPT } \\
\hline & & & & & & & & 1979 & 1980 \\
\hline Primary Commodities & 57. & $\underline{104}$ & 100 & $\underline{106}$ & $\underline{117}$ & $\underline{119}$ & $\underline{154}$ & 145 & $\underline{223}$ \\
\hline Developed Market Economies & 82 & 103 & 100 & 102 & 106 & 115 & 134 & 131 & 155 \\
\hline Developing Market Economies & 44 & 104 & 100 & 108 & 124 & 121 & 165 & 153 & 260 \\
\hline Food & $\underline{87}$ & 111 & 100 & 105 & $\underline{120}$ & 121 & 136 & $\underline{133}$ & 157 \\
\hline Developed Market Economies & 89 & 108 & 100 & 99 & 100 & 113 & 131 & 128 & 149 \\
\hline Developing Market Economies & 83 & 119 & 100 & 118 & 165 & 138 & 148 & 143 & 176 \\
\hline Agricultural Raw Materials & 101 & 120 & $\underline{100}$ & 112 & $\underline{124}$ & $\underline{132}$ & $\underline{159}$ & 158 & $\underline{166}$ \\
\hline Developed Market Economies & 100 & 113 & 100 & 109 & 119 & 124 & 149 & 149 & 153 \\
\hline Developing Market Economies & 103 & 130 & 100 & 118 & 132 & 146 & 175 & 174 & 186 \\
\hline Non Ferrous Metals & $\underline{106}$ & 131 & $\underline{100}$ & $\underline{109}$ & $\underline{117}$ & 126 & $\underline{167}$ & 163 & 188 \\
\hline Developed Market Economies & 100 & 123 & 100 & 108 & 117 & 126 & 165 & 161 & 186 \\
\hline Developing Market Economies & 122 & 150 & 100 & 112 & 117 & 127 & 172 & 168 & 193 \\
\hline Primary Commodities & & & & & & & & & \\
\hline Excluding Petroleum & 85 & 107 & 100 & 106 & $\underline{118}$ & $\underline{121}$ & 138 & 135 & 155 \\
\hline Developed Market Economies & 85 & $103^{\circ}$ & 100 & 102 & 105 & 115 & 132 & 130 & 148 \\
\hline Developing Market Economies & 85 & 116 & 100 & 115 & 144 & 133 & 149 & 146 & 171 \\
\hline
\end{tabular}

Source : United Nations Monthly Bulletin of Statistics, February 1981. 


\section{IV: CURRENT ACCOUNT BALANCES AND FINANCE}

It is clear from table 11 that the world economy suffered another major upheaval in current account balances and financial requirements in 197-1980. Once agair rising ol prices thrust the oil exporter into a very large current arcount surplus --which in real tarms was nearly equivalent tc the 1974 jeak surpus-- while the other ajor ecoromic groups fell into serioui; deficit positions.

In some ways the current stuation represents an improvement over 1974; for instance, in 1980 the industrialized countries (e.g. Germany and Japan) were assuming a relatively large share of the deficits, which could be deemed appropriate because they have the greatest capacity to finance them. Also, on the positive side, the oil price shock apparently did not erode investors'. confidence as much as was the case in 1974.

On the negative side, however, can be found the concern that the oil producers may be much slower in shedding their surpluses than they were during 1974-1978, in part because of an awareness that uncontrolled imports and growth can have undesirable politica1 and social consequences. Meanwhile, the non oil developing countries had to encounter a massive rise in the cost of energy at a time when many still had not fully recovered from the internal and external imbalances created by events in 1974. Then the situation of the oil importing developing countries has been made more precarious by the fact that prolonged stagflation in the industrialized countries is putting increasing pressure on declining industries in the North and is generating new demands for protectionism. On the side of finance there are specters of difficulties because commercial banks --the chief financiers of developing countries' deficits in 1974-1978-- are already very exposed in the heavily indebted Third World 
TABLE 11

WORLD CURRENT ACCOUNT BALANCES $\underline{\mathrm{a}}$ / $\underline{\mathrm{b}} /$

(Billions of dollars)

\begin{tabular}{|c|c|c|c|c|c|c|c|}
\hline & 1974 & 1975 & 1976 & 1977 & 1978 & 1979 & $1980 \mathrm{c} /$ \\
\hline Industrial Cüutrias & -20 & 2 & -16 & -23 & 15 & -36 & -74 \\
\hline Oil Exporting Developing Countries & 60 & 27 & 37 & 29 & 5 & 68 & 115 \\
\hline Non-oil Exporting Developing Countries & -26 & -30 & -18 & -13 & -23 & -36 & -50 \\
\hline Centrally Planned Economies & -10 & -18 & -13 & -9 & -10 & -3 & -7 \\
\hline & & & • & & & & . \\
\hline
\end{tabular}

Source: GATT, Press release, 10 Yarch 1981; OECD Economic Outlook, No.28, December 1980, and Cepal on the basis of official data.

a/ After official tronctiz

b/ Please note that due to different sources of information the country classifications used in this table are not entirely compatible with those employed in earlier tables of this world summary.

c/ Preliminary 
and are showing signs of reluctance with regard to assuming major responsibility in this, the second round of the recycling process. $1 /$

Eut perhaps the most: distressing problem of $a 11$ is that after more than six years af stagflation there appears to be few new i ieas on hrw probler; should be anfronted for the furpose of restoring grow th and prosperity to the worlid economy.

Notwithstanding the worsening of the deficit situation of the developing countries' external accounts, preliminary evidence suggests that there was a decline in borrowing from private international capital markets for the first time in a number of years (see tables 12 and 13) ${ }^{\underline{3} /}$. This can be attributed to factors on both the supply and demand sides. With regard to supply, and as already mentioned, commercial bankers appear to have become reluctant to fully comit themselves to a new round of massive lending to

1/ The commercial banks apparently feel that their capacity to maintain the vigorous rates of growth of lending that the world has become accustomed to will be constrained by prudential concerns and the limiting forces of capital/asset ratios. For an excellent discussion of this issue see Morgan Guaranty Trust Company, World Financial Markets, September 1980 .

2/ The works cited earlier by Lewis, Muller and Thurow contain some of the few available innovative ideas for resolving the current world problems. Another new and innovative contribution to the debate over how to overcome the world economic crisis will be found in the forthcoming book by Raul Prebisch, Capitalismo Periferico: Crisis y Transformacion, Mexico, Fondo de Cultura Económica, 1981.

3/ Aside from the fact that data for 1980 are still very preliminary in nature, the estimates for 1980 probably overstate the fall in borrowing because in this year there appears to have been more recourse to unpublicized borrowing and individual as opposed to large syndicated credits. 
TABLE 12

PUBLICIZED EUROCURRENCY CREDITS

(billions of U.S. dollars or equivalent)

\begin{tabular}{|c|c|c|c|c|c|c|c|c|c|c|}
\hline & 1974 & 1975 & 1976 & 1977 & 1978 & 1979 & 1980 a $/$ & $\frac{\text { Rat }}{1978}$ & $\begin{array}{l}\text { es of } \\
1979\end{array}$ & $\frac{\text { Growth }}{1980}$ \\
\hline TOTAL & $\underline{28.5}$ & $\underline{20.6}$ & $\underline{28.7}$ & 34.2 & 73.7 & 70.2 & $\underline{66.2}$ & 115.5 & -4.8 & -5.7 \\
\hline Industrialized Countries & 17.3 & 5.1 & 8.3 & 11.1 & 31.3 & 19.0 & 28.8 & 182.0 & -39.3 & 51.6 \\
\hline Developing Countries $\underline{b} /$ & 9.7 & 12.5 & 17.3 & 20.2 & 38.3 & 43.2 & 34.5 & 89.6 & 12.8 & -20.1 \\
\hline (Oil Exporters) & $(0.2)$ & $(0.3)$ & $(1.6)$ & $(3.3)$ & $(2.7)$ & $(0.7)$ & $(0.4)$ & $(-18.2)$ & $(-74.1)$ & $(-42.9)$ \\
\hline $\begin{array}{l}\text { Centrally Planned } \\
\text { Economies }\end{array}$ & 1.1 & 2.7 & 2.4 & 2.7 & 3.7 & 7.5 & 2.3 & 37.0 & 102.7 & -69.3 \\
\hline Other & 0.4 & 0.3 & 0.7 & 0.2 & 0.4 & 0.5 & 0.6 & 100.0 & 25.0 & 20.0 \\
\hline
\end{tabular}

Source: World Bank

a/ Preliminary estimate

b/ Please note that the World Bank includes the Mediterranean region of Europe in this group. 
TABLE 13

PUBLICIZED FOREIGN AND INTERNATIONAL BOND ISSUES

(billions of U.S. dollars or equivalent)

\begin{tabular}{|c|c|c|c|c|c|c|c|c|c|}
\hline & \multirow[b]{2}{*}{1975} & \multirow[b]{2}{*}{1976} & \multirow[b]{2}{*}{1977} & \multirow[b]{2}{*}{1978} & \multirow[b]{2}{*}{1979} & \multirow{2}{*}{1980 a/ } & \multicolumn{3}{|c|}{ Growth Rates } \\
\hline & & & & & & & 1978 & 1979 & 1980 \\
\hline TOTAL & $\underline{22.8}$ & 34.3 & 36.1 & 37.5 & 37.8 & 37.1 & 3.9 & 0.8 & -1.9 \\
\hline Industrialized Countries & 16.1 & 23.2 & 22.8 & 22.6 & 24.6 & 25.7 & -0.9 & 8.9 & 4.5 \\
\hline Developing Countries $\underline{b} /$ & 1.0 & 2.3 & 4.8 & 6.1 & 4.0 & 2.9 & 27.1 & -34.4 & -27.5 \\
\hline (0il Exporters) & $(-)$ & $(-)$ & $(0.1)$ & $(0.1)$ & $(-)$ & $(-)$ & $(-)$ & $(-)$ & $(-)$ \\
\hline $\begin{array}{l}\text { Centrally Planned } \\
\text { Economies }\end{array}$ & 0.1 & 0.1 & 0.3 & - & - & - & - & - & - \\
\hline Other & 5.6 & 8.7 & 8.2 & 8.8 & 9.2 & 8.5 & 7.3 & 4.5 & -7.6 \\
\hline
\end{tabular}

\section{Source: World Bank}

a/ Preliminary estimate

b/ Please note that the World Bank includes the Mediterranean region of Europe in tinis group. 
developing countries and as a result they apparently are being more cautious and selective in extending loans. With regard to the demand side, many developing countries preferred to avoid the market in 1980 because lending conditions had become rather onerous. While spreads on eurocurrency credits --by far the most important source of funding--

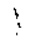
remained low relative to the crisis period of 1975-1976 (see table 14), the base interest rate (LIBOR), which is the most important determinant of interest cost, reached record levels during 1980, averaging $14.15 \%$, compared to $11.99 \%$ in 1979 and $9.36 \%$ and $6.42 \%$ in 1978 and 1977 , respectively. $1 /$ Also there was a noticeable tightening of maturity structures in 1980 (see table 15). In view of market conditions, many countries opted for finance via greater deployment of international reserves, which had been accumulated in considerable amounts in earlier periods when the terms of credit were more attractive, and more use was made of official finance, e.g. new IMF commitments to non-oil developing countries for balance of payments assistance rose from only 2.2 billion dollars in 1979 to 7.2 billion dollars in $1980 . \underline{2}$

1/ Rate for 6-month Eurodollars calculated from data in various issues of Morgan Guaranty's World Financial Markets.

2/ See IMF Survey, February 9, 1981, pp. 38-39. 
TABLE 14

WEIGHTED SPREADS ON VARIABLE INTEREST

EUROCURRENCY CREDITS TO DEVELOPING COUNTRIES a /

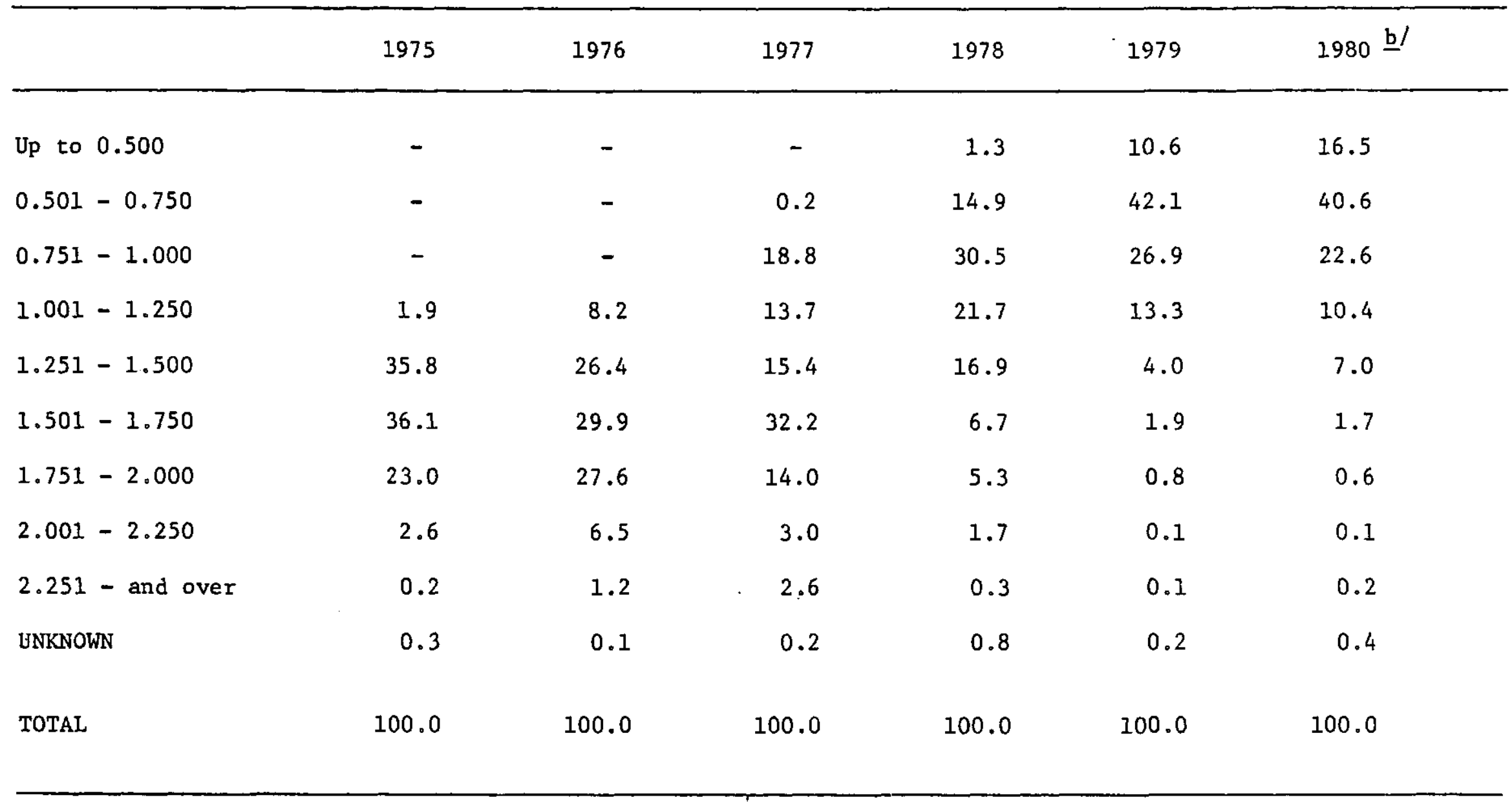

\section{Source: World Bank}

a/ Please note that the World Bank includes the Mediterranean countries of Europe in this classification.

b) Preliminary estimates. 
TABLE 15

ORIGINAL MATURITIES ON EUROCURRENCY CREDITS

TO DEVELOPING COUNTRIES a/

(percentage distribution)

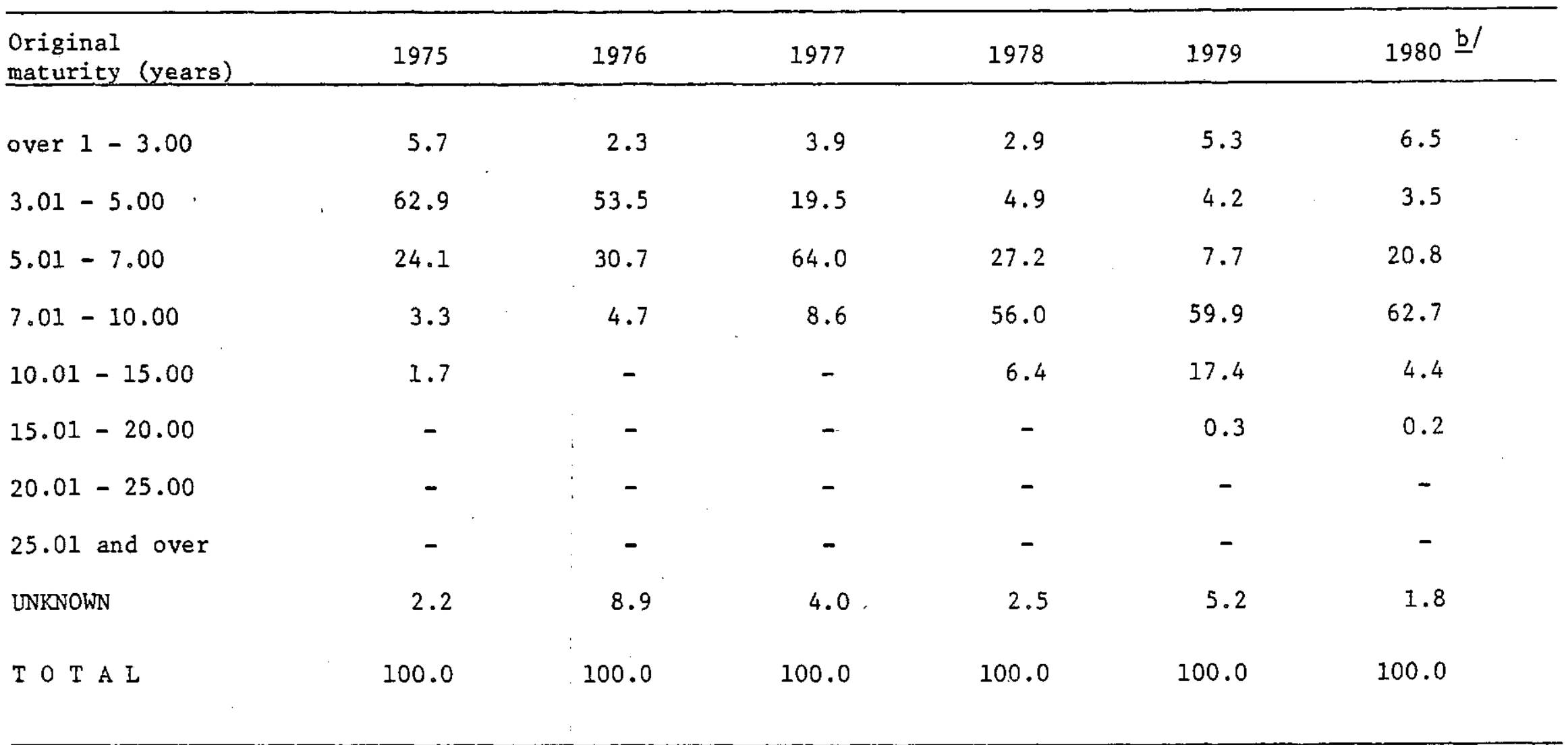

Source: World Bank

a/ Please note that the World Bank includes the Mediterranean countries of Europe in this category.

b/ Preliminary estimates. 
The trend towards more official finance appears to be part of a healthy adjustment in the structure of world financial flows. During the 1970s, commercial banks --fueled as they were by deposits of surplus oil producers-- greatly expanded their lending to LDCs and as a consequence they were able to dwarf the activities of official lenders such as the IMF and World Bank. However, commercial bank lending has tended to be concentrated in the group of upper income developing countries such as those in Latin America, and it would be unreasonable to expect the growth of lending to these countries to exceed the growth rate of the banks" capital base for an indefinite period. $1 /$ Thus new lending from official institutions' would seem to be an appropriate and timely way to restore some balance in the structure, as well as maturity, of international capital flows to developing countries; furthermore, it would relieve some of the pressure on the banks and also provide for a more deliberate and coordinated international adjustment process. For this to happen, however, official institutions must be more successful in directly tapping the OPEC surplus, more than $50 \%$ of which found its way into commercial bank deposits in 1979-1980. $2 /$ In 1980, both the I.M.F. and World Bank made

1/ After 1975 U.S. banks began to slow down their lending to LDCs, but even so, it has grown at a rate of $17 \%$ per annum in face of a $13 \%$ per annum expansion of the capital base. Meanwhile, over the same period non-U.S. banks have been expanding loans to these countries at a rate of $40 \%$ per annum, while the average capital base has risen at only $25 \%$ per annum. See Morgan Guaranty Trust, op. cit., September $1980, \mathrm{p} .8$.

2/ See William J. Gasser, "The Global Payments Problems" Quarterly Review (Federal Reserve Bank of New York), Winter 1980-81, Vo1. 5, No. 4, P. 32 . 
proposals to augment their resources via borrowing agreements with OPEC countries: the IIF has recently reached an agreement to borrow 8 billion SDRs from the Government of Saudi Arabia over the next 2 years, with a tentative agreenent for another 4 billion SDRs in the third yeax, $1 /$ while the World Bank is exploring support for a new energy affiliate which would imply additional resources of up to 12 billion dollars. ${ }^{-}$ These new initiative are welcome and are clearly in the mutual interest of both the North and South. Hopefully these programs represent the initial steps to a more dynamic and expanded role for multilateral lenders during the decade of the 1980 s.

1/ IMF, Morning News, March 30, 1981

2/ See World Bank, Energy in the Developing Countries, August 1980. 
1

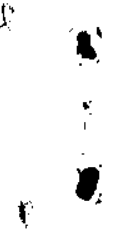

